\title{
Anaerobic prefermentation and primary sedimentation of wastewater in a sequencing batch reactor
}

\author{
Oscar González-Barceló* and Simón González-Martínez \\ Instituto de Ingeniería, Universidad Nacional Autónoma de México, Ciudad Universitaria 04510 D. F., Mexico
}

\begin{abstract}
This research was carried out with the aim of evaluating the solubilisation and acidification capacity of fermenting organisms in suspension in a sequencing batch reactor (SBR), which had a volume of $1800 \ell$. Using $8 \mathrm{~h}$ cycles with 340 min of anaerobic reaction time, the wastewater fed to the SBR presented an average of total and dissolved COD of $315 \mathrm{and} 230 \mathrm{mg} / \ell$. The experiment was divided into three phases: In Phase 1 the organic load was decreased from 1.46 to $0.27 \mathrm{kgCOD} / \mathrm{kgTSS} \cdot \mathrm{d}$, as total COD, during a period of $154 \mathrm{~d}$. If the acidification is defined as the fraction of organic substrate that is transformed to volatile fatty acids (VFA) then the highest acidification percentage $(80 \%)$ of the dissolved $\mathrm{COD}\left(\mathrm{COD}_{\mathrm{D}}\right)$ was obtained for the organic load runs of between 0.62 and $0.72 \mathrm{kgCOD} / \mathrm{kgTSS} \cdot \mathrm{d}$. Within this range of organic load the $2^{\text {nd }}$ and $3^{\text {rd }}$ experimental phases were achieved at the same time after $130 \mathrm{~d}$ while the $\mathrm{pH}$ and temperature were the control parameters: $\mathrm{pH}$ from 5.5 to 7.5 and temperature from 22 to $31^{\circ} \mathrm{C}$. Finally, the higher production level of the dissolved COD during the fermentative reaction period was $35 \mathrm{mg} / \ell$. The acidification of the dissolved influent COD was increased from 50 to $60 \%$ by decreasing the $\mathrm{pH}$ from 7.0 to 5.5 and this percentage was doubled from 33 to $66 \%$ when the temperature was increased from 22 to $31^{\circ} \mathrm{C}$. All of the dissolved effluent COD was in the form of VFA, when an organic load of $0.62 \mathrm{kgCOD} / \mathrm{kgTSS} \cdot \mathrm{d}$ was used or when the temperature was increased up to $31^{\circ} \mathrm{C}$. The VFA production rate that was achieved after $80 \mathrm{~min}$ diminished by half when the solids retention time (SRT) was decreased from 8 to $2 \mathrm{~d}$ or when the temperature was lowered from 31 to $24^{\circ} \mathrm{C}$.
\end{abstract}

Keywords: prefermentation, hydrolysis, volatile fatty acids, wastewater

\section{Introduction}

If the prefermentation phase of biological pathways in anaerobic degradation (hydrolysis or liquefaction and acidogenesis) is used, a greater proportion of the readily biodegradable COD (RBCOD) can be obtained to be fed directly to the downstream biological treatment process (Rössle and Pretorius, 2001). Goncalves et al., 1994, Wentzel and Ekama, 1997 and Münch et al., 1999 report on the subject of the basic principles of prefermentation in wastewaters:

- Micro-organisms responsible for enzymatic reactions are found in the sewage solids

- In order to increase the RBCOD they carry out extracellular hydrolysis of organic particulate or complex matter, the hydrolysis rates often being the limiting factor

- A portion of the RBCOD is used to synthesise cellular structure (growth), another fraction to produce VFA with the implicit production of $\mathrm{CO}_{2}$. The remainder is used for the only possible loss of total $\mathrm{COD}$ through $\mathrm{H} / \mathrm{CO}_{2}$ production.

The RBCOD which is not transformed into VFA leaves the SBR as $\mathrm{COD}_{\mathrm{D}}$ and is discharged from the system in the effluent. Ligero et al. (2001a) relate the advantages of the anaerobic prefermenter fed with wastewater: When the prefermenter is designed as an activated primary tank (APT) (Barnard, 1984) or as a hydrolytic upflow sludge bed reactor (HUSB) (Ligero et al., 2001a) the system can achieve the function of a primary settler. The sludge in the prefermenter is stabilised, partially, at the same

\footnotetext{
* To whom all correspondence should be addressed.

獣 + (52) 55-56-23-3669; fax: +(52) 55-56-16-2164;

e-mail: $\operatorname{ogb} @$ pumas.iingen.unam.mx

Received 14 February 2006; accepted in revised form 1 September 2006.
}

time as the SRT proportioned for the prefermenter is increased. The fermentative bacteria increase the biodegradability of the remaining COD by producing RBCOD while the COD particulate is diminished. A higher fraction of RBCOD favours the subsequent biological elimination of nutrients $(\mathrm{N}, \mathrm{P})$.

The present study was undertaken with the aim to determine the fermentative capacity of the biomass retained in an SBR reactor when fed with municipal wastewater and operated under various organic loads.

\section{Materials and methods}

\section{Analytical methods}

Parameters determined in the influent and effluent were total $\mathrm{COD}\left(\mathrm{COD}_{\mathrm{T}}\right)$ and dissolved $\mathrm{COD}\left(\mathrm{COD}_{\mathrm{D}}\right)$, total suspended solids (TSS), temperature, $\mathrm{pH}$, nitrogen as ammonium $\left(\mathrm{NH}_{4}^{-}\right.$ $\mathrm{N})$, nitrate $\left(\mathrm{NO}_{3}-\mathrm{N}\right)$ and total Kjeldahl nitrogen $(\mathrm{TKN}-\mathrm{N})$, phosphorus as orthophosphate $\left(\mathrm{PO}_{4}-\mathrm{P}\right)$ and volatile fatty acids (VFA). $\mathrm{COD}_{\mathrm{D}}$ and VFA were determined during fermentation cycles. Standard Methods (1989) was employed to determine all the parameters, except for VFA determination. The VFA were determined by means of gas chromatography (HP-5890 Serie II) using an AT-1000 column (Alltech, $10 \mathrm{~m}$ x $0.53 \mathrm{~mm}$ ID, $1.2 \mu \mathrm{m}$ ); samples were filtered through $0.45 \mu \mathrm{m}$. The VFA concentrations were expressed as $\mathrm{COD}\left(\mathrm{VFA}_{\mathrm{COD}}\right)$.

\section{Wastewater characteristics}

The sewage was collected in the influent of the wastewater treatment plant of the National University of Mexico. By adding maltodextrine and corn gluten hydrolysed protein to the wastewater, the total and dissolved COD was increased from 120 and $80 \mathrm{mg} / \ell$ to 315 and $230 \mathrm{mg} / \ell$, respectively. The average of the 


\begin{tabular}{|c|c|c|c|c|c|c|c|}
\hline & & Wastews & $\begin{array}{l}\text { TABLE } 1 \\
\text { ter charac }\end{array}$ & teristic & & & \\
\hline Concentration & & $\begin{array}{l}\text { COD } \\
\mathrm{mg} / \ell)\end{array}$ & 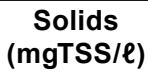 & Forn & $\begin{array}{l}\text { Is of nitr } \\
(\mathrm{mgN} / \mathrm{l})\end{array}$ & ogen & \begin{tabular}{|c} 
Phosphorus \\
(mgP/l)
\end{tabular} \\
\hline & Total & Dissolved & Total & $\mathrm{NH}_{4}-\mathrm{N}$ & $\mathrm{NO}_{3}-\mathrm{N}$ & TKN-N & $\mathrm{PO}_{4}-\mathrm{P}$ \\
\hline Average & 305 & 230 & 105 & 15 & 3 & 30 & 3 \\
\hline Standard deviation & 49 & 53 & 28 & 6 & 1 & 17 & 1 \\
\hline
\end{tabular}

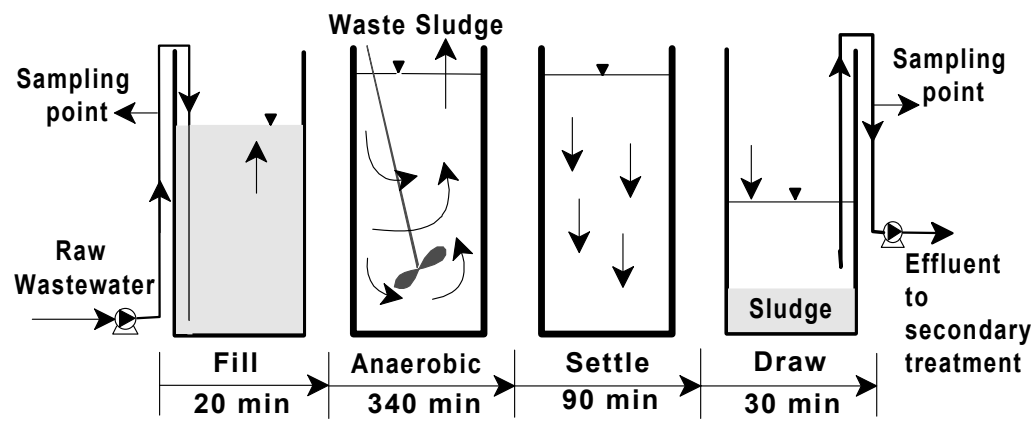

Figure 1

Anaerobic prefermentation of wastewater in a batch reactor wastewater characteristics fed to the prefermenter was obtained through composite samples collected over $24 \mathrm{~h}$. The $\mathrm{COD}_{\mathrm{T}}$ and $\mathrm{COD}_{\mathrm{D}}$ were measured every day. The others parameters were measured three times a week (Table 1). The sampling was conducted over the duration of the entire experiment. The $\mathrm{pH}$ and temperature were measured in situ daily and their average and standard deviation were $7.4 \pm 0.3$ and $20 \pm 4^{\circ} \mathrm{C}$, respectively.

\section{Sequencing batch reactor}

The sequencing batch reactor (SBR) and the principles of the activated primary tank (APT) (Barnard, 1984) were combined in this study in order to use the SBR as a primary settler and prefermenter of municipal wastewater (Cuevas-Rodríguez et al., 1998). The settled sludge is retained in the SBR to combine with the sewage inflow (Fig. 1). Subsequently, the anaerobic reaction is achieved with a complete mixing. In contrast to the APT, the entire SBR volume is occupied by the micro-organisms enabling them to carry out the hydrolysis and acidogenesis processes. Afterwards, the solids resettle to elutriate (wash out) the VFA formed in the SBR ( Münch and Koch, 1999; Rössle and Pretorius, 2001).

A pilot SBR with an active volume of $1800 \ell$ (Fig. 1) was operated over $8 \mathrm{~h}$ cycles. The cycles were divided into fill, anaerobic, settling and draw, and modified from that proposed by Irvine and Ketchum (1989). Mixing was achieved with a mechanical agitator. Excess sludge was wasted daily from the mixed liquor before the onset of settling. Table 2 shows the experimen- tal procedure: During Phase 1 the parameter of control was the organic loading rate. This was decreased for the different runs of organic load from 1.46 to $0.27 \mathrm{kgCOD} / \mathrm{kgTSS} \cdot \mathrm{d}$. The latter was used during the last trial of the Phase 1. Every time one run was finished, the amount of waste sludge was decreased for the next run. This was maintained at a constant level in order to allow an increase of the mixed liquor suspended solids. A lower organic load was obtained with respect to the previous one. The highest VFA production with respect to the dissolved COD in the influent was obtained when the organic load was maintained at between 0.62 and $0.72 \mathrm{kgCOD} / \mathrm{kgTSS} \cdot \mathrm{d}$. Phase 2 included the operation of the batch reactor with a constant organic load while the $\mathrm{pH}$ was the control parameter with values decreased from 7.5 to 5.5. A pH controller was used and the $\mathrm{pH} 5.5$ and 6.0 were maintained at a constant level in the corresponding runs by adding phosphoric acid. Caustic soda was used to reach the other $\mathrm{pH}$ levels of 6.5, 7.0 and 7.5 (Table 2). The temperature was considered the parameter of control for Phase 3. The experimental runs from 22 to $31^{\circ} \mathrm{C}$ were adjusted at a constant level by using an electrical resistance and a controlling device (Table 2).

\section{Results}

\section{Phase 1: Influence of the organic load}

\section{Organic load}

After every run the amount of sludge wasted was reduced in order to obtain a higher TSS concentration for the next SBR test

\begin{tabular}{|c|c|c|c|c|c|c|c|c|}
\hline Experi & ntal $p$ & ases & $\begin{array}{l}\text { ABL } \\
\text { th di }\end{array}$ & ent $c$ & trol p & amet & & \\
\hline Phase 1: Selection o & e org & c loac & terva & th the & ghest & idific & on de & \\
\hline Runs & 1 & 2 & 3 & 4 & 5 & 6 & 7 & 8 \\
\hline Organic load $\left(\frac{\mathrm{kgCOD}}{\mathrm{kgSS} \cdot \mathrm{d}}\right)$ & 1.46 & 1.30 & 1.13 & 0.77 & 0.72 & 0.62 & 0.48 & 0.27 \\
\hline Phase 2: Different ph & reac & com & ned w & the se & tion c & organ & load & \\
\hline Runs & 1 & 2 & 3 & 4 & & & & \\
\hline $\mathrm{pH}$ & 7.5 & 7.0 & 6.5 & 6.0 & & & & \\
\hline Phase 3: Different te & eratu & of rea & on co & ined $v$ & the $s$ & ection & forga & cload \\
\hline Runs & 1 & 2 & 3 & 4 & & & & \\
\hline Temperature $\left({ }^{\circ} \mathrm{C}\right)$ & 22 & 24 & 28 & 30 & & & & \\
\hline
\end{tabular}




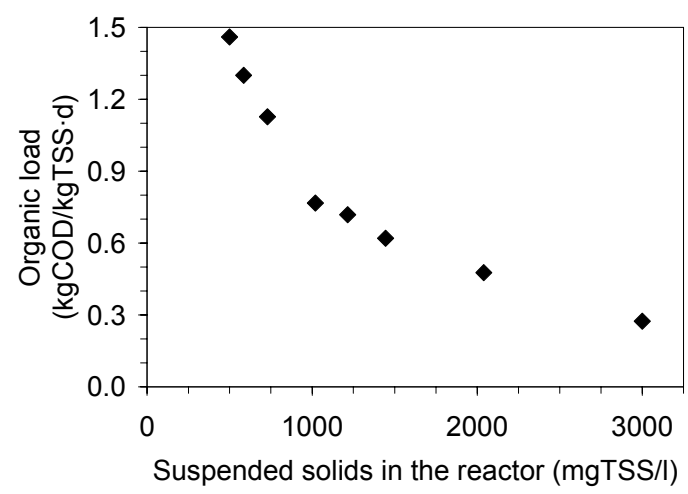

Figure 2

The TSS were maintained at a constant level during each organic load in the SBR

and consequently a lower organic load (Fig. 2). A range of suspended solids (SS) in the mixed liquor from a minimum of 500 up to a maximum of $3000 \mathrm{mgTSS} / \ell$ was necessary in the SBR to obtain the decreasing organic load intervals of 1.46 to 0.27 $\mathrm{kgCOD} / \mathrm{kgTSS} \cdot \mathrm{d}$, respectively (Table 3 ).

\begin{tabular}{|c|c|c|}
\hline \multicolumn{3}{|c|}{ TABLE 3 } \\
TSS required in the SBR and SRT obtained for the \\
different organic loads \\
\hline $\begin{array}{c}\text { Organic load } \\
\left(\frac{\mathrm{kgCOD}}{\mathrm{kgSS} \cdot \mathrm{d}}\right)\end{array}$ & $\begin{array}{c}\text { Suspended solids } \\
\text { in the reactor } \\
\text { (mgTSS/l) }\end{array}$ & $\begin{array}{c}\text { SRT } \\
\text { (d) }\end{array}$ \\
\hline $1.46 \pm 0.23$ & $500 \pm 90$ & $1.9 \pm 0.4$ \\
\hline $1.30 \pm 0.25$ & $585 \pm 125$ & $1.9 \pm 0.8$ \\
\hline $1.13 \pm 0.32$ & $730 \pm 170$ & $3.5 \pm 1.2$ \\
\hline $0.77 \pm 0.06$ & $1020 \pm 78$ & $3.7 \pm 1.2$ \\
\hline $0.72 \pm 0.03$ & $1215 \pm 84$ & $5.5 \pm 1.2$ \\
\hline $0.62 \pm 0.03$ & $1445 \pm 25$ & $6.4 \pm 0.5$ \\
\hline $0.48 \pm 0.12$ & $2040 \pm 325$ & $7.3 \pm 3.1$ \\
\hline $0.27 \pm 0.05$ & $3000 \pm 220$ & $15.6 \pm 2.2$ \\
\hline
\end{tabular}

\section{Sludge retention time (SRT)}

The acidogenic bacteria are faster-growing than the methanogenic bacteria, and process control through cellular age management is thus guided to ensure that the desired bacterial content remains in the reactor (Rössle and Pretorius, 2001).

Irvine and Ketchum (1989) define the SRT in the mixed batch reactor as a reciprocal equivalent to the total suspended solids mass fraction that leaves the system on a daily basis (waste solids plus solids that escape in the effluent).

Eastman and Ferguson (1981) identified hydrolysis of particulate organic matter to dissolved substrate as the rate-limiting step during the acid generation phase of anaerobic digestion (Banister and Pretorius, 1998). Verstraete and Vandevivere (1997) claimed that an independent handling of the variables defined for the hydraulic residence time (HRT) and SRT in a fermentative biological system can be useful to overcome the low hydrolysis rates of particulate solids. In this research, in which the duration of the cycles was always $8 \mathrm{~h}$, a minimum SRT of $2 \mathrm{~d}$ and a maximum of $16 \mathrm{~d}$ were obtained for the maximum and minimum organic load, 1.46 and $0.27 \mathrm{kgCOD} / \mathrm{kgTSS} \cdot \mathrm{d}$, respectively (Table 3 ). It illustrates the versatility of the mixed batch reactor for controlling the SRT and HRT separately.

The authors Münch et al. (1999) experimented with COD $_{\text {D }}$ of 110 and $230 \mathrm{mgCOD} / \ell$ and with HRT intervals for that varied between 0.5 and $24 \mathrm{~h}$. These authors adjusted the SS return flow and achieved an SRT of between 0.1 and $11 \mathrm{~d}$. According to Lilley et al. (1990), $8 \mathrm{~d}$ represent a maximum appropriate limit for the cellular age when it is necessary to limit the methanogenic activity in a prefermenter. This can be achieved with organic loads of equal or higher than $0.48 \mathrm{kgCOD} / \mathrm{kgTSS} \cdot \mathrm{d}$ (Fig. 3).

Rössle and Pretorius (2001) mentioned that there is no universal cellular age suitable for all prefermenters, due to variable local conditions. Banister and Pretorius (1998), decided to limit the SRT to $6 \mathrm{~d}$ in their experiments. A range between 4 and $6 \mathrm{~d}$ for the SRT was reported in this work for organic loads of between 0.62 and $0.77 \mathrm{kgCOD} / \mathrm{kgTSS} \cdot \mathrm{d}$ (Fig. 3).

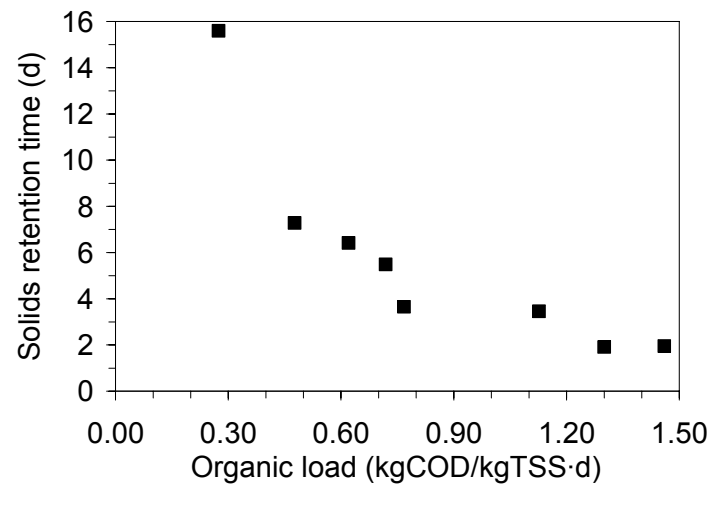

Figure 3

Relation between SRT and organic load by using an SBR as fermenter

\section{Removal of suspended solids}

The minimum concentration of TSS that was obtained in the effluent of the SBR reactor corresponded to $60 \mathrm{mgTSS} / \ell$ for the organic load of $1.46 \mathrm{kgCOD} / \mathrm{kgTSS} \cdot \mathrm{d}$ (Fig. 4). The corresponding influent TSS was $80 \mathrm{mgTSS} / \ell$, the minimum value measured during the phase 1 , and the removal was only $25 \%$. The concentrations in the influent showed a maximum of $170 \mathrm{mgTSS} / \ell$ for the organic load of $0.27 \mathrm{kgCOD} / \mathrm{kgTSS} \cdot \mathrm{d}$ (Fig. 4) and the corresponding value in the effluent was $80 \mathrm{mgTSS} / \ell$. The highest solids removal efficiency $55 \%$ was obtained with the latter run (Fig. 4). In another anaerobic system in which raw sewage is fed into the bottom and travels upwards through a sludge blanket, known as hydrolytic upflow sludge bed reactor (HUSB), Ligero et al. (2001a) obtained similar suspended solids in the effluent, $70 \mathrm{mgTSS} / \ell$ for solids in the influent of $240 \mathrm{mgTSS} / \ell$. A solids removal efficiency of $70 \%$ was reached (Table 4 ).

Goncalves et al. (1994) in the experiment with the HUSB reactor, for an HRT of $2.8 \mathrm{~h}$ report that a solids reduction of 148 to $45 \mathrm{mgTSS} / \ell$ was achieved between the influent entering

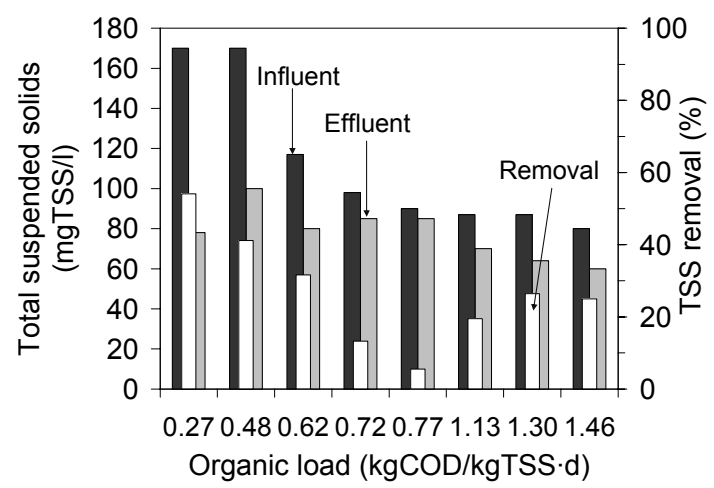

Figure 4

Influent and effluent SS for the batch fermentative reactor 
the system and the effluent leaving the system. A solids removal efficiency of $70 \%$ was obtained (Table 4 ).

Using biofilms is a different form of cellular age control. Cuevas and Tejero (2003) used a fixed submerged bed biofilm reactor to preferment wastewater. A clarifier was installed at the effluent point in order to retain the biological solids from the prefermenter. When the concentrations in the influent were 165 and $202 \mathrm{mgTSS} / \ell$ for 2 and $0.5 \mathrm{~h}$ of HRT, Cuevas and Tejero (2003) obtained averages for the effluent solids of 56 and 70 $\operatorname{mgTSS} / \ell$. A solids removal efficiency of $65 \%$ was maintained and a removal efficiency of $70 \%$ was achieved when these authors managed to decrease the TSS levels from $87 \mathrm{mgTSS} / \ell$ in the influent down to $26 \mathrm{mgTSS} / \ell$ in the effluent (Table 4 ) by increasing the HRT from 2 to $4 \mathrm{~h}$.

\begin{tabular}{|l|l|c|c|}
\hline \multicolumn{4}{|c|}{ TABLE 4 } \\
\begin{tabular}{|l} 
Maximum solids removal obtained for distinct \\
prefermenters used as primary settler
\end{tabular} \\
\hline $\begin{array}{l}\text { Reactor } \\
\text { type }\end{array}$ & References & $\begin{array}{c}\text { HRT } \\
\text { (h) }\end{array}$ & $\begin{array}{c}\text { Solids removal } \\
\text { efficiency (\%) }\end{array}$ \\
\hline HUSB & Goncalves et al. (1994) & 2.8 & 70 \\
\hline HUSB & Ligero et al. (2001a) & 4.4 & 70 \\
\hline $\begin{array}{l}\text { Biofilm } \\
\text { reactor }\end{array}$ & Cuevas and Tejero (2003) & 4.0 & 70 \\
\hline SBR & Present work & 8.0 & 55 \\
\hline
\end{tabular}

\section{Temperature and $\mathrm{pH}$}

The $\mathrm{pH}$ and temperature were maintained at a constant value during the Phase 1 . The average values were $6.3 \pm 0.2$ for the $\mathrm{pH}$ and $17.3 \pm 0.6^{\circ} \mathrm{C}$ for the temperature.

\section{Total COD removal}

Because the sewage concentrations and flows were influenced by the university activities, influent COD variations were obtained. A maximum value of $375 \mathrm{mgCOD} / \ell$ was measured for the corresponding organic load of $0.48 \mathrm{kgCOD} / \mathrm{kgTSS} \cdot \mathrm{d}$ (Fig. 5). The lowest total COD influent was 270 for $1.46 \mathrm{kgCOD} /$ kgTSS $d$ (Fig. 5). The total COD removal was between 15 and $30 \%$ (Fig. 5). Goncalves et al. (1994) reported results for total COD removal of $30 \%$ for an HRT of $1.1 \mathrm{~h}$. Cuevas and Tejero (2003) removed $30 \%$ of $\mathrm{COD}_{\mathrm{T}}$ in $4 \mathrm{~h}$ and $22 \%$ in $0.5 \mathrm{~h}$. Ligero et

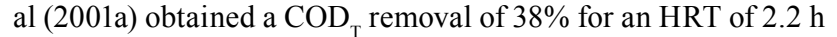
in an HUSB reactor.

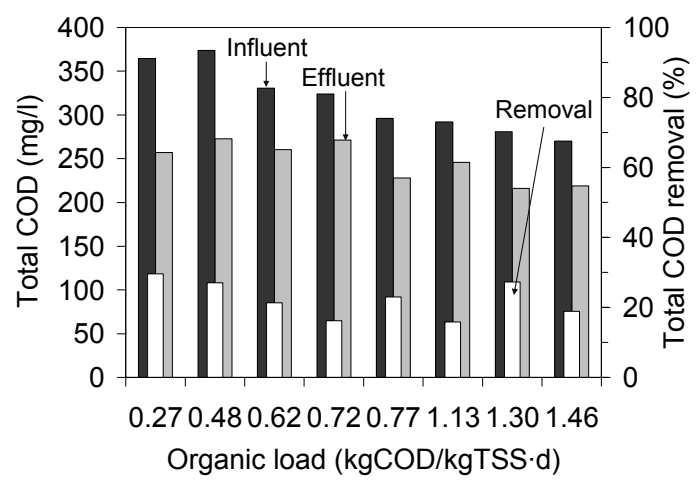

Figure 5

Total COD removal in the prefermentative batch reactor

\section{Dissolved COD and solubilisation}

For the maximum and minimum organic loads, 1.46 and 0.27 $\mathrm{kgCOD} / \mathrm{kgTSS} \cdot \mathrm{d}$, the influent dissolved COD was 210 and 240 $\operatorname{mgCOD} / \ell$, respectively (Table 5 ). The $\mathrm{COD}_{\mathrm{D}}$ at the effluent

\begin{tabular}{|c|c|c|c|c|}
\hline \multicolumn{5}{|c|}{$\begin{array}{c}\text { TABLE } 5 \\
\text { Dissolved COD and VFA measured in the } \\
\text { fermentative batch reactor }\end{array}$} \\
\hline \multirow{2}{*}{$\begin{array}{l}\text { Organic } \\
\text { load } \\
(\text { kgCOD/ } \\
\text { kgTSS·d) }\end{array}$} & \multicolumn{3}{|c|}{ Dissolved COD } & \multirow{2}{*}{$\begin{array}{l}\text { Total VFA } \\
\text { Production } \\
\text { (mg/l as } \\
\text { COD) }\end{array}$} \\
\hline & $\begin{array}{c}\text { Influent } \\
\left(m^{\prime} \operatorname{COD}_{\mathrm{D}} / \ell\right)\end{array}$ & $\begin{array}{c}\text { Effluent } \\
\left(m g C O D_{D} / \ell\right)\end{array}$ & $\begin{array}{c}\text { Removal } \\
(\%)\end{array}$ & \\
\hline 1.46 & 210 & 170 & 20 & 143 \\
\hline 1.30 & 230 & 160 & 28 & 111 \\
\hline 1.13 & 230 & 175 & 23 & 131 \\
\hline 0.77 & 230 & 150 & 36 & 148 \\
\hline 0.72 & 245 & 195 & 20 & 194 \\
\hline 0.62 & 215 & 175 & 27 & 177 \\
\hline 0.48 & 245 & 165 & 33 & 151 \\
\hline 0.27 & 240 & 170 & 29 & 147 \\
\hline
\end{tabular}

was maintained at a constant value, $170 \mathrm{mgCOD}_{\mathrm{D}} / \ell$. The $\mathrm{COD}_{\mathrm{D}}$ removal efficiency was increased from 20 to $29 \%$. These percentages are similar to the removal level of 17 to $28 \%$, obtained by Ligero et al. (2001b) who worked with SRTs of higher than $13 \mathrm{~d}$ and HRTs of between 2.2 and $4.4 \mathrm{~h}$.

A parameter that was evaluated in the prefermenter corresponds to solubilisation, considered to be the production of $\mathrm{COD}_{\mathrm{D}}$ by the breakdown of the particulate fraction of the wastewater. The latter is calculated by subtracting the COD portion filtered through $0.45 \mu \mathrm{m}$ pore thickness from the total COD (Goncalves et al., 1994).

The greater part of the $\mathrm{COD}_{\mathrm{D}}$ removal shown in Table 5 was achieved during the start of the fill phase to the SBR; for example, the $\mathrm{COD}_{\mathrm{D}}$ was decreased from 240 to $145 \mathrm{mgCOD}_{\mathrm{D}} / \ell$ during a cycle for $0.27 \mathrm{kgCOD} / \mathrm{kgTSS} \cdot \mathrm{d}$ (Fig. 6). With respect to the $\mathrm{COD}_{\mathrm{D}}$ production, on Fig. 6 is shown the highest production of dissolved COD through the anaerobic phase in the case of the lowest organic load level, $0.27 \mathrm{kgCOD} / \mathrm{kgTSS} \cdot \mathrm{d}$. The $\mathrm{COD}_{\mathrm{D}}$ at the end of the cycle improved the concentration measured at the beginning of the anaerobic reaction with an increase of $34 \mathrm{mgCOD}_{\mathrm{D}} / \ell$, but not sufficiently to reach the influent $\mathrm{COD}_{\mathrm{D}}$.

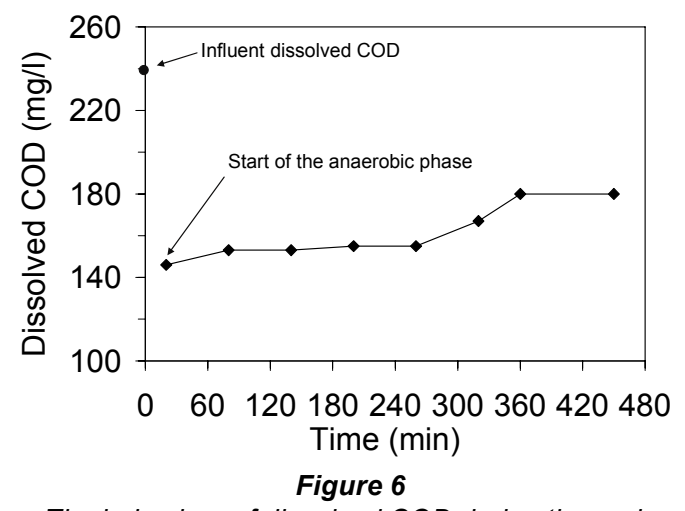

The behaviour of dissolved COD during the cycle corresponding to $0.27 \mathrm{kgCOD} / \mathrm{kgTSS} \cdot d$

Among the research done on dissolved COD production in an anaerobic pretreatment, is the work reported by Barajas et al. (2002) in their activated primary tank with an HRT of $1.3 \mathrm{~h}$ and an SRT of $5 \mathrm{~d}$, the mean increase in the effluent $\mathrm{COD}_{\mathrm{D}}$ was $22 \mathrm{mg} / \ell$.

Cuevas-Rodriguez and Tejero-Monzón, (2003) achieved a higher $\mathrm{COD}_{D}$ in the effluent with respect to the influent by using a fixed bed reactor. For HRTs of 0.5 and $4 \mathrm{~h}$, they achieved productions of 17 and $20 \mathrm{mgCOD}_{\mathrm{D}} / \ell$, respectively. 
In an HUSB reactor Goncalves et al. (1994) managed to obtain a $\mathrm{COD}_{\mathrm{D}}$ production when the HRT remained at between 2.1 and $4.3 \mathrm{~h}$ and the SRT between 3.2 and $14.8 \mathrm{~d}$. The maximum dissolved COD production was $30 \mathrm{mg} / \ell$ for $2.8 \mathrm{~h}$ of HRT and $7.4 \mathrm{~d}$ of SRT.

\section{VFA production}

Another evaluated process with respect to the fermentation was the production of VFA originating from the particulate and dissolved COD (Goncalves et al., 1994). The different organic loads ensured that no less than $70 \%$ of the $\mathrm{COD}_{\mathrm{D}}$ measured in the effluent was in the form of VFA (Fig. 7). All the effluent $\mathrm{COD}_{\mathrm{D}}$ was in the form of VFA for $0.62 \mathrm{kgCOD} / \mathrm{kgTSS} \cdot \mathrm{d}$.

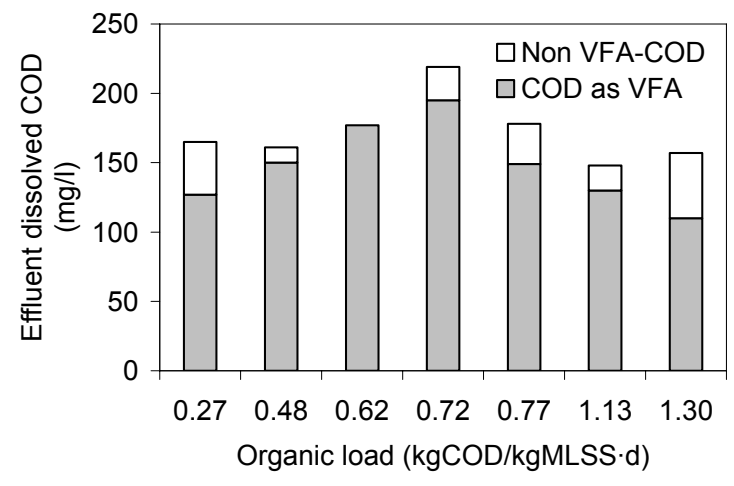

Figure 7

Composition of the dissolved COD in the effluent

Cuevas and Tejero (2003) determined in their work that about $44 \%$ of the soluble compounds quantified in the acidified effluent were VFA. Similar fraction to $42 \%$ obtained by Ligero et al. (2001a) for $2.8 \mathrm{~h}$. Goncalves et al. (1994) determined 57\% as VFA for an HRT of $2.8 \mathrm{~h}$ in the composition of the dissolved COD of the effluent.

The percentage of acidification with respect to the $\mathrm{COD}_{\mathrm{D}}$ of the influent was always over $50 \%$ (500 $\mathrm{mg}$ of VFA produced as COD per gram of $\mathrm{COD}_{\mathrm{D}}$ in the influent) with a maximum of $79 \%$ for an organic load of $0.72 \mathrm{kgCOD} / \mathrm{kgTSS} \cdot \mathrm{d}$ (Fig. 8). Barajas et al. (2002) with their activated primary tank acidified $27 \%$ of the influent $\mathrm{COD}_{\mathrm{D}}$, attributing that most of the influent $\mathrm{COD}_{\mathrm{D}}$, was not in contact with the fermenting sludge for long enough. Ligero et al. (2001a) found that for an HRT of $3.4 \mathrm{~h}$ the acidification increased within the range 22 to $30 \%$ of the $\mathrm{COD}_{\mathrm{D}}$. This percentage was incremented for Goncalves et al., (1994) with an HUSB reactor to $38 \%$ for an HRT of $2.8 \mathrm{~h}$. Cuevas and Tejero (2003) achieved a maximum acidification of $56 \%$ with respect to

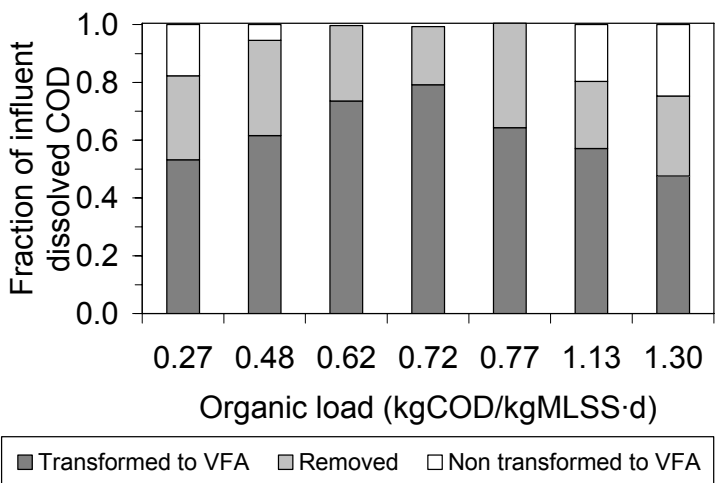

Figure 8

Acidification of the dissolved COD under different organic load the influent dissolved COD for an HRT of $4 \mathrm{~h}$ in a biofilm reactor. The mixing conditions in the batch reactor would ensure that a higher proportion of dissolved COD was in contact with the fermenting biomass.

The highest acidification degree of the dissolved COD was obtained for the organic load interval of between 0.62 and 0.72 $\mathrm{kgCOD} / \mathrm{kgTSS} \cdot \mathrm{d}$. It was adopted for the $2^{\text {nd }}$ and $3^{\text {rd }}$ phases in which the control parameters were the $\mathrm{pH}$ and the temperature of reaction.

\section{Phase 2: Influence of the $\mathrm{pH}$}

\section{Production of VFA and dissolved COD}

The second experimental phase was achieved with a temperature of $23 \pm 1.8^{\circ} \mathrm{C}$ and an organic load of $0.63 \pm 0.14 \mathrm{kgCOD} / \mathrm{kgTSS} \cdot \mathrm{d}$ under different $\mathrm{pH}$ (Table 2). The acidification of the $\mathrm{COD}_{\mathrm{D}}$ transformed to VFA was increased from 50 to $63 \%$ when the $\mathrm{pH}$ was decreased from 7.5 to 5.5 (Fig. 9).

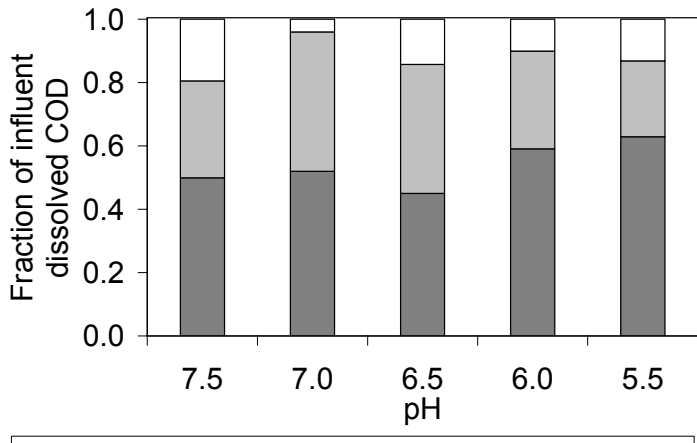

$\square$ Transformed to VFA $\square$ Removed $\square$ Non transformed to VFA

Figure 9

Influence of the $\mathrm{pH}$ over the acidogenic activity

The highest production of dissolved COD, $36 \mathrm{mg} / \ell$, was achieved when the $\mathrm{pH}$ was maintained at a constant level of 6.5 during the cycles (Fig. 10)

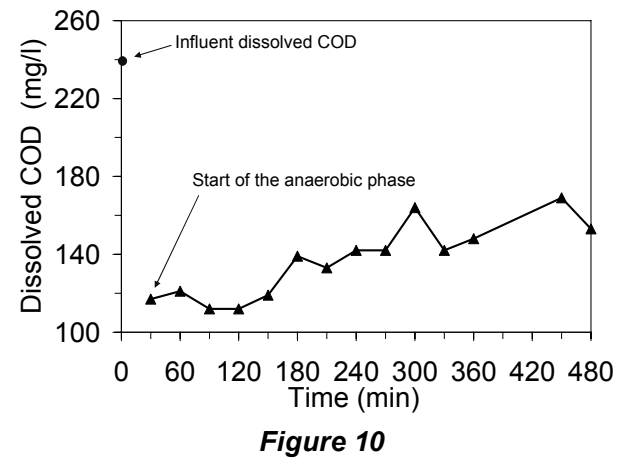

The highest production of dissolved $C O D$ in the anaerobic phase corresponding to $\mathrm{pH}$ of 6.5

\section{Phase 3: Influence of the temperature}

\section{Production of VFA and dissolved COD}

The third experimental phase included the temperature control by submerging an electrical resistance in the SBR. A different temperature was adjusted for every experimental run. All of the $3^{\text {rd }}$ phase was achieved with an organic load of $0.69 \pm 0.15 \mathrm{kgCOD} /$ $\mathrm{kgTSS} \cdot \mathrm{d}$ and a $\mathrm{pH}$ of $6.3 \pm 0.3$.

The acidification percentage was doubled from 33 to $66 \%$ when the temperature of the anaerobic reaction was increased 
from 22 to $31^{\circ} \mathrm{C}$. Almost all of the influent $\operatorname{COD}_{\mathrm{D}}(98 \%)$ was metabolised by fermentative micro-organisms for the temperature of $31^{\circ} \mathrm{C}$ (Fig. 11). All the $\mathrm{COD}_{\mathrm{D}}$ was utilised only for the first phase with the organic load from 0.62 to $0.77 \mathrm{kgCOD} / \mathrm{kgTSS} \cdot \mathrm{d}$ (Fig. 8)

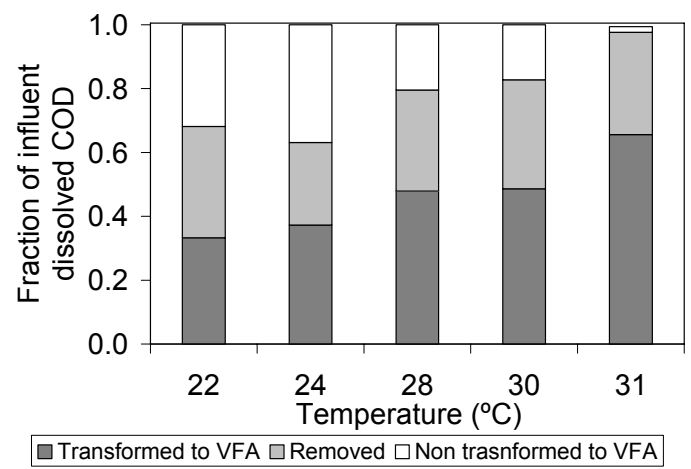

Figure 11

Influence of the temperature in the acidogenic activity

The production of dissolved COD during the anaerobic reactions was not increased compared with the experiments of organic load and $\mathrm{pH}$. With a temperature of $24^{\circ} \mathrm{C}$ it was possible to obtain an increase of $31 \mathrm{mg} \mathrm{COD} / \ell$ during the anaerobic reaction (Fig. 12).

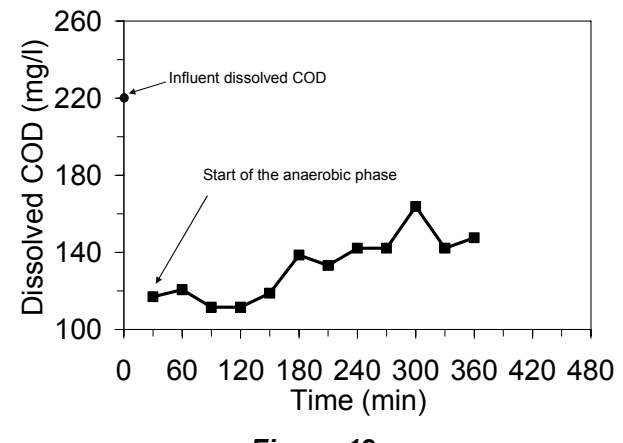

Figure 12

The highest production of dissolved COD in the anaerobic phase corresponding to temperature of $24^{\circ} \mathrm{C}$

\section{VFA production rate}

The VFA production rate can be determined for every minute elapsed during the fermentative cycles. Figure 13 shows that the VFA rate decrease is inversely proportional to the time and to the organic load. Since the latter is inversely proportional to the biomass (Table 3 ) the VFA rate increase is directly proportional to the mass of micro-organisms and the SRT.

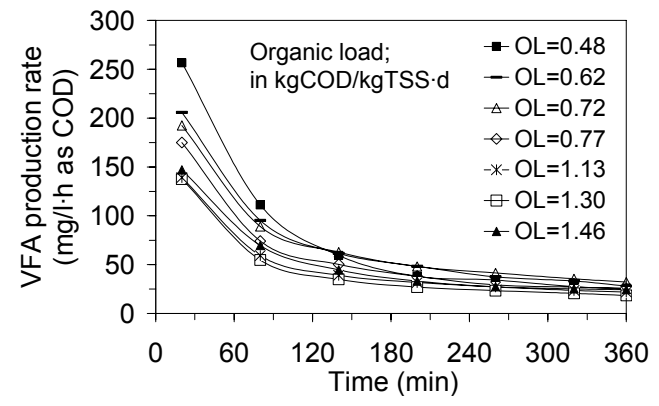

Figure 13

VFA production rate for different organic loads with respect to the anaerobic time
The highest rate of production of the VFA was at the beginning of the reaction (Fig. 13). However, the VFA production rate curves for the different organic loads were very close when the anaerobic time in the acidogenic mixed reactor was longer than $180 \mathrm{~min}$.

The VFA production rate was not influenced by the $\mathrm{pH}$ conditions in the reactor (Fig. 14). The acidification rate has constant value when the anaerobic period of time is longer than $180 \mathrm{~min}$.

Figure 15 showed that the VFA production rate is directly proportional to the temperature. In this case, the VFA rate was influenced during a longer anaerobic time when the temperature was higher.

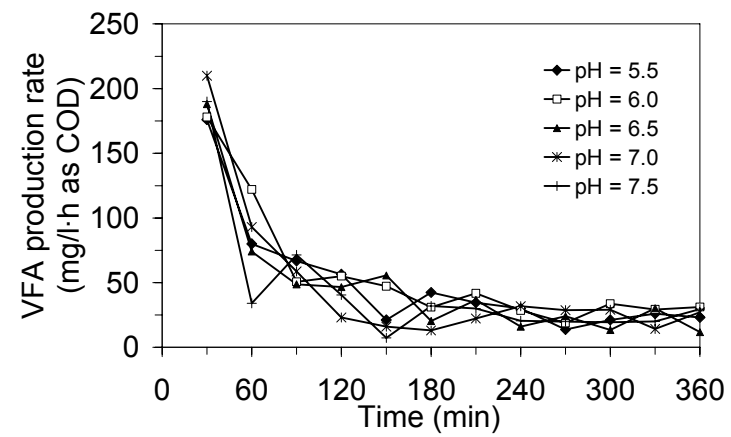

Figure 14

VFA production rate for different $\mathrm{pH}$ with respect to the anaerobic time

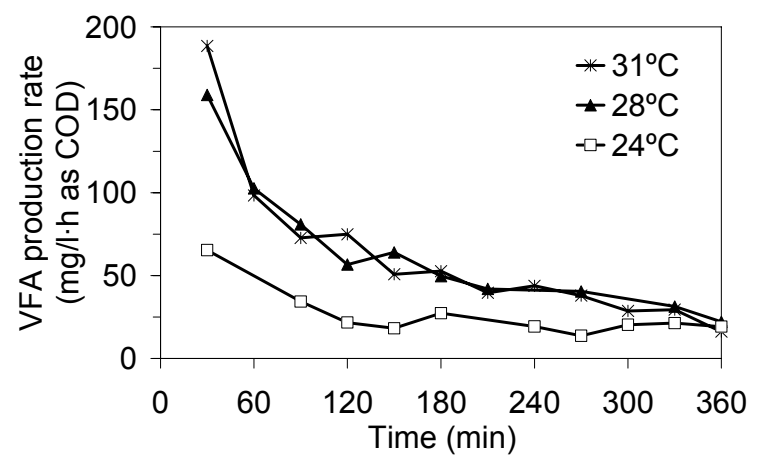

Figure 15

VFA production rate for different temperatures with respect to the anaerobic time

\section{Conclusions}

A mixed batch reactor was used under varying conditions of organic load, $\mathrm{pH}$ and temperature in order to evaluate the fermentative capacity of the suspended biomass fed with wastewater.

Acting as a primary settler, a maximum solids removal efficiency of $55 \%$ was obtained with the SBR reactor. The authors that used in-line prefermenters as the HUSB and the biofilm reactor reached an efficiency of $70 \%$.

The dissolved influent COD removal was maintained at between 20 and $30 \%$; similar values were obtained for the total COD removal.

The production of dissolved COD, $34 \mathrm{mg} / \ell$, obtained during the anaerobic reaction when the SBR reactor was operated under an organic load of $0.27 \mathrm{kgCOD} / \mathrm{kgTSS} \cdot \mathrm{d}$ or $\mathrm{pH}$ of 6.5 or temperature of $24^{\circ} \mathrm{C}$ is similar to the maximum dissolved COD production reported by other authors. 
By obtaining $79 \%$ of the dissolved influent COD transformed in VFA, when an organic load of $0.72 \mathrm{kgCOD} / \mathrm{kgTSS} \cdot \mathrm{d}$ was used, vs. the $56 \%$ obtained in the biofilm reactor and $40 \%$ in the upflow sludge reactor, the capacity of the batch reactor to acidify a higher proportion of the influent dissolved COD was shown with respect to the other in-line configurations.

The percentage of the influent dissolved COD transformed to volatile fatty acids was doubled when the temperature of the anaerobic reaction was changed from 22 to $31^{\circ} \mathrm{C}$.

The production rate of VFA was inversely proportional to the organic load for anaerobic times less than $3 \mathrm{~h}$. For times of between 3 and $6 \mathrm{~h}$ the VFA production rate curves for the different organic loads were very close.

The VFA production rate was directly proportional to the temperature during the anaerobic reaction.

The $\mathrm{pH}$ of the reaction did not have a significant influence over the percentage of dissolved influent COD transformed to VFA and the VFA production rate.

\section{Acknowledgements}

We would like to thank Ignacio Pérez, Zoraya Pérez and Jaime Domínguez for their contribution in the laboratory and experimental area and DGAPA-UNAM for the support No IN119406.

\section{References}

BANISTER SS and PRETORIUS WA (1998) Optimisation of primary sludge acidogenic fermentation for biological nutrient removal. Water SA 24 (1) 35-41.

BARAJAS MG, ESCALAS A and MUJERIEGO R (2002) Fermentation of a low VFA wastewater in an activated primary tank. Water SA 28 (1) 89-98.

BARNARD JL (1984) Activated primary tanks for phosphate removal. Water SA 10 (3) 121-126.

CUEVAS-RODRIGUEZ G, GONZALEZ-BARCELO O and GONZALEZ-MARTINEZ S (1998) Wastewater fermentation and nutrient removal in sequencing batch reactors. Water Sci. Technol. 38 (1) $255-264$.
CUEVAS-RODRÍGUEZ G and TEJERO-MONZÓN I (2003) Sedimentation and prefermentation of domestic wastewater in a fixed bed biofilm reactor. Water Sci. Technol. 48 (3) 47-55.

EASTMAN J A and FERGUSON J F (1981) Solubilisation of particulate organic carbon during the acid phase of anaerobic digestion. J. Water Pollut. Control Fed. 53 352-366.

GONCALVES RF, CHARLIER AC and SAMMUT F (1994) Primary fermentation of soluble and particulate organic matter for wastewater treatment. Water Sci. Technol. 30 (6) 53-62.

IRVINE RL and KETCHUM LLH (1989) Sequencing batch reactors for biological wastewater treatment. Crit. Rev. Environ. Control 18 (4) 255-294.

LIGERO P, VEGA A and SOTO M (2001a) Pretreatment of urban wastewaters in a hydrolytic upflow digester. Water SA 27 (3) 399-404.

LIGERO P, VEGA A and SOTO M (2001b) Influence of HRT (hydraulic retention time) and SRT (solids retention time) on the hydrolytic pre-treatment of urban wastewater. Water Sci. Technol. 44 (4) 7-14.

LILLEY ID, WENTZEL MC, LOEWENTHAL RE, EKAMA GA and MARAIS GvR (1990) Acid Fermentation of Primary Sludge at $20^{\circ} \mathrm{C}$. WRC Research Report No W64. Water Research Commission (Pretoria) and Foundation for Research Development (Pretoria), Department of Civil Engineering, University of Cape Town, Cape Town.

MÜNCH E, KELLER J, LANT P and NEWELL R (1999) Mathematical modelling of prefermenters - I. Model development and verification. Water Res. 33 (12) 2757-2768.

MÜNCH E and KOCH F A (1999) A survey of prefermentation design, operation and performance in Australia and Canada. Water Sci. Technol. 39 (6) 105-112.

RÖSSLE WH and PRETORIUS WA (2001) A review of characterization requirements for in-line prefermenters. Paper 2: Process characterisation. Water SA 27 (3) 413-422.

STANDARD METHODS (1989) Standard Methods for the Examination of Water and Wastewater (17 ${ }^{\text {th }}$ edn.) APHA-AWWA-WPCF, Washington.

VERSTRAETE W and VANDEVIVERE P (1997) Broader and newer application of anaerobic digestion. Proc. $8^{\text {th }}$ Int. Conf. on Anaerobic Digestion. 1. 25-29 May, Sendai, Japan. 67-74.

WENTZEL MC and EKAMA GA (1997) Principles in the design of single-sludge activated sludge systems for the biological removal of carbon, nitrogen, and phosphorus. Water Environ. Res. 69 (7) $1222-1231$ 